Pacific Journalism Review

v.3 no.2 November 1996

\title{
The contempt case of the 'Tongan Three'
}

\section{David Robie}

Media commentators see the recent jailings of two journalists and an MP whistleblower in Tonga as the most serious threat to media freedom in the South Pacific since the Fiji coups in 1987. But Fiji Prime Minister Sitiveni Rabuka sees the harsh move as a lesson for journalists. Other critics regard the issue as one of a need for greater professionalism.

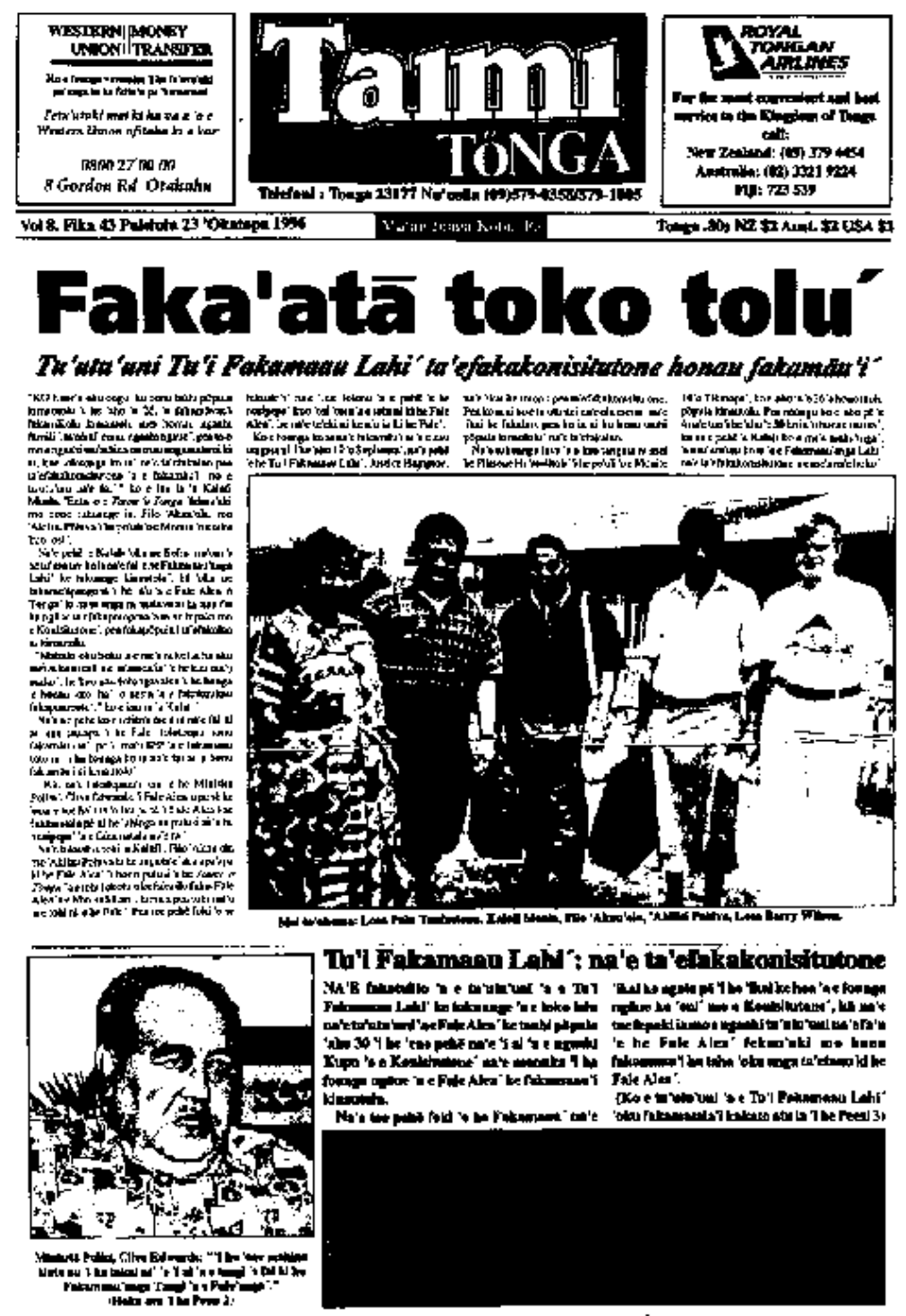

The Tongan Times ... the 'freedom' issue. 
GAGS, threats, defamation cases with the threat of bankruptcy and vilification are nothing new to Samuela 'Akilisi. The pro-democracy movement leader who has been a broadcaster and publishes a best-selling 'muckraking' newsletter has faced everything he thought the establishment in the kingdom of Tonga could throw at him.

But the imprisonment of commoner MP Pohiva and two journalists for 30 days in September 1996 for contempt of Parliament shocked media and human rights circles in the Pacific and internationally. Pohiva, arguably the best-known whistleblower in the region, has waged a decade-long campaign for open government and he exposed the notorious Tongan passportsfor-sale scandal in the newsletter Kele'a.

Many media commentators see the jailings in Tonga as the most serious threat to media freedom in the South Pacific since the Fiji coups in 1987, and Fiji Prime Minister Sitiveni Rabuka, who led the coups, sees the harsh move as a lesson for journalists. Other critics, including a spokesperson for the Commonwealth Journalists Association, regard the issue as one of a need for greater professionalism.

Feuding between some media organisations over the support campaign for the jailed three Pohiva, Taimi 'o Tonga editor 'Eakalafi Moala and subeditor Filokalafi 'Akau'ola - also added a curious twist to the affair. Although Australian news media largely ignored the jailings, in spite of a parallel with five journalists having faced jail or fines in recent contempt of court cases, several [p. 10] organisations treated the issue seriously - including the Australian Centre for Independent Journalism (ACIJ), which established a daily 'Tongan jailings update' on its Online Journalist website <acij.uts.edu.au>.

One of the jailed men, 'Akau'ola, had been detained for 24 hours in February 1996 after his newspaper published a letter criticising Police Minister Clive Edwards. An Auckland-based Agence France-Presse correspondent, Michael Field, who has reported Tongan affairs closely, was barred from entering the kingdom for the Pacific Islands News Association (PINA) in August because of alleged critical writing.

The three men walked free on October 14 after serving just three weeks of their sentence when the Tongan Supreme Court ruled that they had been detained illegally in violation of the Constitution.

New Zealand civil rights lawyer Barry Wilson, acting for the Commonwealth Press Union, told Pacific Journalism Review from Nuku'alofa that their release was encouraging for emerging democratic freedoms in the kingdom. 'The court found that the three had not been covered by the normal safeguards for a trial provided under the constitution,' he said. 'Therefore it came to the conclusion that they were being illegally detained.'

Wilson successfully filed a writ of habeas corpus on October 11 after two earlier attempts had failed. Wilson said: 'I'm also not happy with the jail conditions under which the men are being held.' He added they were being treated differently as political prisoners. Amnesty International declared the three men prisoners of conscience, and international media freedom groups and human rights movements mounted several appeals for their release.

A petition organised by the ACIJ and Pacific Media Watch and signed by more than 170 academics, journalists, media commentators and students - including teachers from St 
Joseph's International School in Port Moresby - was faxed to King Taufa'ahau Tupou IV seeking his intervention to free the men.

Pohiva had been jailed for contempt of Parliament on September 20 after having leaked an impeachment notice against Justice Minister Tevita Tupou. Moala and 'Akau'ola were jailed for publishing the leaked document in a front-page story in the Taimi 'o Tonga .

The Supreme Court found that constitutional provisions such as Clause 10 for trials and sentencing under law, and Clause 11 providing for indictments, defence procedures and the right to call witnesses were breached. It also ruled that the three men had not been correctly found guilty by the Legislative Assembly of the offence they were accused of under Clause 70 of the constitution. The Tongan government defended its parliamentary action, saying the journalists broke the law and should be accountable. [p. 11]

The latest furore erupted after outspoken weekly newspaper Taimi 'o Tonga (Tongan Times) published a Tongan-language story on September 4 under the headline 'PARLIAMENT IMPEACHES MINISTER FOR JUSTICE' about an untabled impeachment notice alleging abuse of office against Justice Minister Tevita Tupou.

As the Tongan government has tried in the past to silence Pohiva and journalists who have tried to shed light on the maladministration of cabinet and Parliament, it moved quickly to stifle dissent over the jailings by suspending the Legislative Assembly on October 4 until the middle of 1997.

King Taufa'ahau Tupou IV used his powers as absolute monarch to close the House after it had voted to impeach Justice Minister Tupou. Tonga's 30-member Legislative Assembly is dominated by 21 unelected representatives of the kingdom's noble families (cabinet ministers are appointed by the King) plus nine elected people's representatives.

Shocked Tongans interpreted the closing of Parliament as a way for the monarch to 'buy time' for the nobles to regroup as the House faces growing democratic demands. The decision to close the Legislative Assembly, which normally sits until mid-November, was announced in a radio broadcast but the palace would not comment further.

According to New Zealand Herald Pacific affairs reporter John Manukia, [p. 12] himself a Tongan, leaders from the Tongan community did not wish to be identified because they feared that they might be looked upon as questioning the king's authority.

Kalafi Moala challenged Parliament over the 'historical trial', claiming the three had been given a prejudiced hearing. In an article in the Taimi 'o Tonga headlined 'WE DIDN'T GET A FAIR TRIAL' [see pp. 13-14 in this issue], Moala defended his paper's action in publishing an untabled motion seeking the impeachment of Justice Minister Tevita Tupou for allegedly going to the Atlanta Olympics and being paid full parliamentary allowances.

'We firmly believe we didn't do anything wrong,' wrote Moala. 'What we published was factual and truthful. It is true that the people's representatives had already signed a petition calling for the impeachment of the Justice Minister because he travelled to the Olympics even though his request for leave was refused.' [p. 14] 
Moala said it was also true that the motion had been registered and placed in the deputy speaker's files so had been already in the parliamentary process. 'This newspaper only reported that the petition had been submitted, the allegations of the petition, and who were the MPs who had signed it.'

Amnesty International declared the three prisoners of conscience - a term the organisation uses to describe people who are in any form of detention because of their political, religious or other conscientiously held beliefs - provided that they have not used or advocated violence. In a letter on September 23 to the King, Amnesty International urged the Tongan head of state to exercise his powers to lift the detention orders 'immediately and unconditionally'.

Amnesty said it believed the three men had been imprisoned as a result of their peaceful exercise of the right to freedom of expression, guaranteed by Article 19 of the Universal Declaration of Human Rights and protected by Article 19 of the International Covenant on Civil and Political Rights.

The organisation noted that Clause 7 of the Tongan Constitution of 1875 states: 'It shall be lawful for all people to speak write and print their own opinions and no law shall ever be enacted to restrict this liberty. There shall be freedom of speech and of the press for ever but nothing in this clause shall be held to outweigh the law of slander or the laws for the protection of the King and the royal family.' But the Tongan government reacted bitterly over the flood of international criticism about the jailings, claiming that the men had set themselves up to be 'martyrs' and accusing press freedom and other organisations of waging a campaign of'"media terrorism' against the kingdom.

Acting Chief Secretary 'Eseta Fusitu'a said the government had received a series of 'incorrect, unjust, biased and malicious' press condemnation following the jailings and called on protesting media organisations to publish the 'facts'. In a 'background' statement defending government actions faxed to several protesting media organisations on September 26, including Pacific Journalism Review and the ACIJ, Fusitu'a claimed the issue was not one of 'freedom of the press, nor the right of the public to be informed about matters of public interest'. She said the issues were 'the right of the House and the Minister for Justice to be reported truthfully, and the right of the people to correct information' in a newspaper.

Both of these are fundamental human rights, and are the elementary demands of the principles of natural justice. Both rights, however, were violated by Moala, 'Akau'ola and Pohiva, and are still being violated by many overseas organisations and media services.

Despite this most regrettable reality, of media terrorism against Tonga, we are still hopeful that reputable media services will one day ask for the facts, and will one day publish them. [p.15]

Fusitu'a acknowledged Agence France-Presse news agency, Radio Australia and Radio New Zealand for contacting the government to seek information, but condemned a 'blacklist' of protesting media organisations. Fusitu'a criticised the World Press Freedom Committee (USA), Australian Centre for Independent Journalism (Sydney), Pacific Journalism Review (PNG), National Press Club (PNG), Pacific Star Pty Ltd (publishers of The National, PNG), International Press Institute (France), Word Publishing Co Ltd (PNG), NZ Journalists 
Training Organisation (NZ), NZ Engineering Printing and Manufacturing Union, Amnesty International (UK), the New Zealand Herald and many other print and radio media.

'The history of the media provides very meagre evidence of voluntary corrections of misinformation. To do so is bad for the actual authors of the misinformation, for the reputation of the media organisation, and of course for their sales,' Fusitu'a said. However, a spokesperson for Pacific Media Watch said the Tongan government had failed to recognise the difference between the role of 'news gathering' media organisations and those 'protesting' over the jailing.

Among other reactions, the International Federation of Journalists, the world's largest organisation of journalists, representing more than 400,000 journalists in 95 countries, expressed 'dismay' and appealed for their release. 'This act of punishment is a clear violation of freedom of expression and opinion,' said senior vice-president Christopher Warren in a letter to the King. 'Given the widespread anxiety of human rights organisations and journalist colleagues in the Asia-Pacific region, I hope you will intervene to release unconditionally those journalists that have been jailed. The IFJ also asks you to intervene to guarantee the rights of journalists in Tonga, who belong to our member organisation, the Pacific Journalists Association.’

Warren said the IFJ was concerned that this attempt to punish and intimidate journalists and to impose systems of media control 'are an offence to democracy and undermine the capacity of people to participate openly in society'.

In other reaction, The National newspaper of Papua New Guinea and the Fiji Times published harshly critical editorials on the Tongan government. The National described the kingdom as an 'archaic monarchy' and said it needed to change: "'Libelling the Legislative Assembly" is a weak excuse. Upsetting the King would be more to the point.' Gagging the three men with jail terms would 'keep the country in the dark ages', warned The National. 'That era belonged in the 15th and 16th centuries. Today even the famous British monarchy is agonising over its role and trying to change its ancient ways to fit into modern times.' [p. 16]

The Fiji Times said: 'It has driven home the fact that freedom of expression is very much under threat in the Pacific and could very well become a reality in Fiji. The authorities say "negative" reports show a lack of respect for them and any such criticism is immediately labelled "culturally insensitive" - the facade they hide behind to prevent scrutiny of their actions.' The Times praised the courage of Moala, 'Akau'ola and Pohiva. However, Fiji Prime Minister Sitiveni Rabuka said his country had 'no business' interfering with the Tongan government's media policy and regards it as a warning to local journalists. While media freedom of expression in Fiji is guaranteed by the constitution, according to the coup leader, the media has a role to protect that freedom by ensuring at all times that it reports 'accurately and fairly'.

A rift between several Tongan journalists and the major regional media organisation, Pacific Islands News Association (PINA), which primarily represents [p. 18] the publishers and owners, and its newly created Pacific Freedom of Information Network, burst into the open. Following a deputation to the king by PINA's administrator Nina Ratulele to seek the jailed men's release, a move widely welcomed in the region, PINA executive director Tavake Fusimalohi angrily resigned. Fusimalohi, general manager of Radio Tonga and a longtime PINA stalwart but personally opposed to Pohiva, was quoted by Radio Australia as saying he 
had resigned over 'personal attacks' against him and the local PINA affiliate, Tonga News Association, by PINA president, Monica Miller, of American Samoa. Fusimalohi says she had accused them of remaining silent over the jailing of their Tongan colleagues. But Miller appealed to journalists in the region not to lose sight of the main reason why the three men were jailed - the Taimi 'o Tonga had published information which the people of Tonga had a right to know.

The jailings have been the latest confrontation between Pohiva and the Tongan establishment which is opposed to open and accountable government. During 1993, Pohiva faced five lawsuits - three libel cases involving damages totalling 180,000 pa'anga, and two gagging actions seeking to prevent him publishing information considered confidential in his newsletter Kele'a, and also to make him reveal his sources.

'If these actions succeed it will silence the news media - it will effectively shut down a free press in Tonga,' said Auckland lawyer Nalesoni Tupou, who had himself become exiled from his homeland because of his legal work on behalf of Pohiva.

Although Pohiva lost defamation cases totalling more than 60,000 pa'anga in damages, he remained defiant. But he believed the Tongan establishment was trying to destroy him by making him bankrupt.

[p. 19]

Copyright (C) 1996 David Robie/Pacific Journalism Review

David Robie is lecturer in journalism at the University of Papua New Guinea and co-director of Pacific Media Watch. At the time of writing this article, published in Reportage Media Bulletin, Issue No 7, 1996, he was attached with the Australian Centre for Independent Journalism on a media research program.

This edition was assisted with funding by the Communication Assistance Foundation (CAF) of The Netherlands.

November 1996 Pacific Journalism Review

(C) Asia Pacific Network and the individual contributors and authors 